Article

\title{
Complete Mitogenome of a Leaf-Mining Buprestid Beetle, Trachys auricollis, and Its Phylogenetic Implications
}

\author{
Lifang Xiao ${ }^{1,3, \dagger}$, Shengdi Zhang ${ }^{1,+}$, Chengpeng Long ${ }^{1}$, Qingyun Guo ${ }^{1}$, Jiasheng $\mathrm{Xu}^{1}$, \\ Xiaohua Dai ${ }^{1,2, *}$ and Jianguo Wang ${ }^{3}$ \\ 1 Leafminer Group, School of Life Sciences, Gannan Normal University, Ganzhou 341000, China; \\ xiaolifang@cnu.edu.cn (L.X.); 18645133878@163.com (S.Z.); lchp617650632@gmail.com (C.L.); \\ guoqingyun@gnnu.edu.cn (Q.G.); 0900048@gnnu.edu.cn (J.X.) \\ 2 National Navel-Orange Engineering Research Center, Ganzhou 341000, China \\ 3 College of Agriculture, Jiangxi Agricultural University, Nanchang 330045, China; jgwang@jxau.edu.cn \\ * Correspondence: xiaohuadai@gnnu.edu.cn; Tel.: +86-137-6398-8183 \\ + Both authors contributed equally to this work.
}

Received: 23 October 2019; Accepted: 28 November 2019; Published: 1 December 2019

\begin{abstract}
A complete mitogenome of Trachys auricollis is reported, and a mitogenome-based phylogenetic tree of Elateriformia with all protein-coding genes (PCGs), rRNAs, and tRNAs is presented for the first time. The complete mitochondrial genome of T. auricollis is $16,429 \mathrm{bp}$ in size and contains 13 PCGs, two rRNA genes, 22 tRNA genes, and an A + T-rich region. The A + T content of the entire genome is approximately $71.1 \%$, and the AT skew and GC skew are 0.10 and -0.20 , respectively. According to the the nonsynonymous substitution rate to synonymous substitution rates $(\mathrm{Ka} / \mathrm{Ks})$ of all PCGs, the highest and lowest evolutionary rates were observed for atp 8 and cox1, respectively, which is a common finding among animals. The start codons of all PCGs are the typical ATN. Ten PCGs have complete stop codons, but three have incomplete stop codons with T or TA. As calculated based on the relative synonymous codon usage (RSCU) values, UUA(L) is the codon with the highest frequency. Except for trnS1, all 22 tRNA genes exhibit typical cloverleaf structures. The A + T-rich region of T. auricollis is located between rrnS and the trnI-trnG-trnM gene cluster, with six 72-bp tandem repeats. Both maximum likelihood (ML) and Bayesian (BI) trees suggest that Buprestoidea is close to Byrrhoidea and that Buprestoidea and Byrrhoidea are sister groups of Elateroidea, but the position of Psephenidae is undetermined. The inclusion of tRNAs might help to resolve the phylogeny of Coleoptera.
\end{abstract}

Keywords: Buprestoidea; Byrrhoidea; Elateroidea; Scirtoidea; Elateriformia; mitochondrial genome; phylogeny

\section{Introduction}

The Buprestoidea superfamily comprises two families: Buprestidae and Schizopodidae. Schizopodidae is a small family with only seven species in three genera [1], whereas Buprestidae is the eighth largest family in Coleoptera, with approximately 15,000 species in 522 genera [2,3]. Thus far, only six mitogenome sequences of Buprestoidea have been submitted to the NCBI database, with four genera of Buprestidae and no record of Schizopodidae [4]. The genus Trachys F. belongs to the tribe Tracheini (Elateriformia: Buprestoidea: Buprestidae: Agrilinae), with 637 species in the Afrotropical, Australasian, Oriental, and Palaearctic regions [3]. The tribe Tracheini contains mainly small and cuneiform leaf- or stem-mining beetles [5,6]. Trachys auricollis Saunders 1873 includes two synonym species: T. sauteri Kerremans 1912 and T. freyi Théry 1942. T. auricollis is widely distributed in Asia [3,7], 
and damage due to either larval mining or adult feeding can lead to a reduction in plant photosynthesis and growth [8]. As a specialist herbivore, the leaf-mining beetle is also the most promising biocontrol agent for kudzu [9], a seriously invasive plant in the USA [10]. There are no bioinformatic studies on the mitogenome of T. auricollis to date.

With highly specialized larvae and adults, Buprestoidea is problematic about its monophyly [11]. Moreover, there are different views regarding the phylogenetic relationship of Buprestoidea with other Elateriformia superfamilies such as Byrrhoidea, Elateroidea, and Dascilloidea (Figure 1) [11-13]. In contrast to the traditional placement of Scirtoidea in Elateriformia [13-15], Scirtoidea/Scirtiformi is now treated as one basal group of Polyphaga [16-18]. Nosodendridae is occasionally placed in Elaterioformia $[16,18]$. The relationship between Buprestoidea, Byrrhoidea, and Elateroidea is the focus of our study. Some taxonomists have argued that Buprestoidea is a monophylum with a position either inside or outside byrrhoid lineages, with Elateroidea being a sister clade to Buprestoidea and Byrrhoidea (Figure 1) [12-14,19-22]. However, several recent studies have indicated that Byrrhoidea and Elateroidea have a close relationship and that Buprestoidea is located outside their group [17,23,24]. Conversely, according to Duan et al. (2017), Buprestoidea is the basal Polyphaga branch and is isolated from all other Elateriformia superfamilies [25].
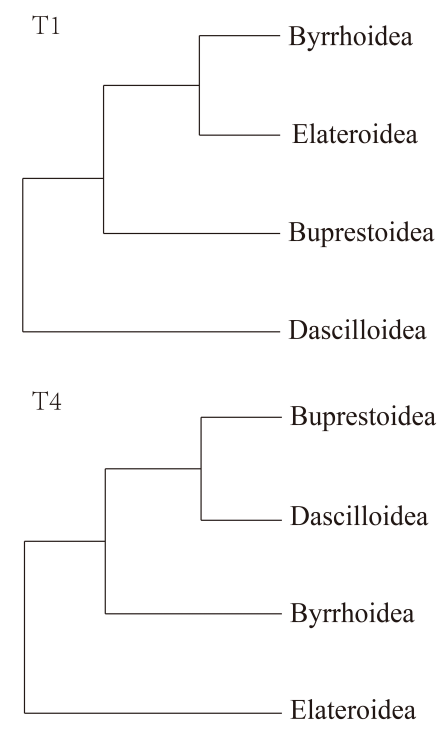

T7

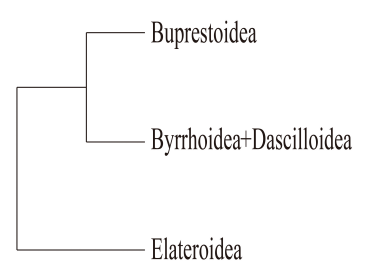

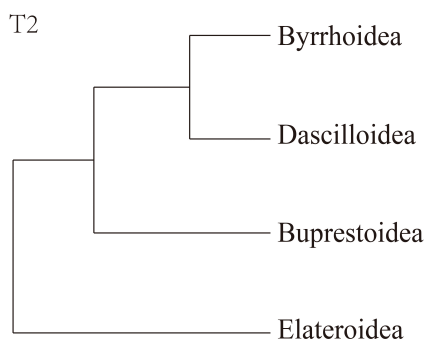

T5

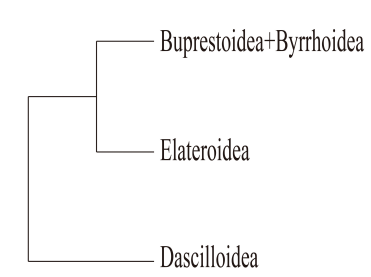

T8

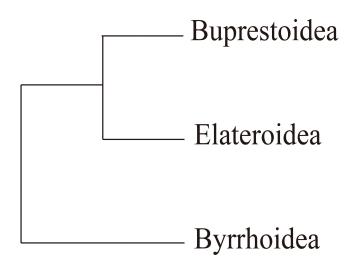

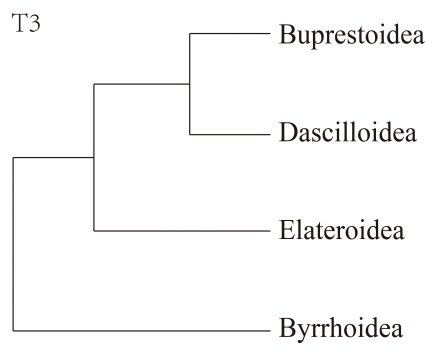

T6

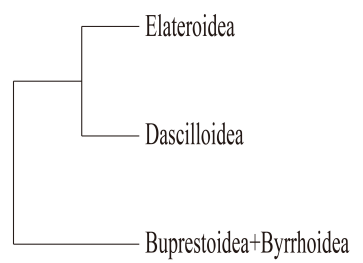

T9

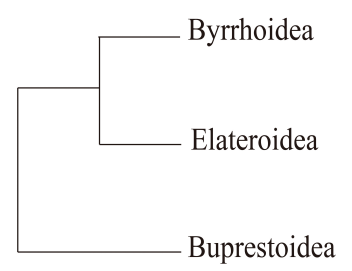

Figure 1. Nine gene-based topologies among four superfamilies of Elateriformia. Topologies are derived from: T1 refs. [16,17], T2 ref. [26], T3 ref. [27], T4 ref. [26], T5 refs. [28-30], T6 ref. [18], T7 ref. [26], T8 ref. [31], and T9 refs. [23-25].

Insect mitogenomes are closed-circular molecules of approximately $16 \mathrm{~kb}$ in length, with 37 genes and a noncoding A + T-rich region [32-36]. Mitogenomes have been widely utilized to analyze population genetics, phylogeography, and molecular phylogenetics at different taxonomic levels [37-40]. Furthermore, mitochondrial protein-coding genes (PCGs), rRNAs, tRNAs, and their combinations have been adopted to explore species differentiation and phylogenetic problems [41-43]. tRNAs are traditionally considered to be inappropriate phylogenetic markers because of their short length, duplication, horizontal transfer, or even change in specificity [44]. However, the overall set of tRNAs 
in each complete genome could reflect a stable phylogeny [44]. tRNA sequence and structure might provide additional useful information to solve phylogenetic problems, especially at higher taxonomic levels [44-46]. The inclusion of tRNAs has improved phylogenetic resolution in several insect groups including Diptera, Orthoptera, Neuropterida, and Lepidoptera [43,47-49]. Thus far, however, there has been no adoption of tRNAs to resolve the Elateriformia phylogeny (Table 1). This is the first report that uses all PCGs, rRNAs, and tRNAs to dissect phylogenetic relationships in Elateriformia, especially the complicated relationship among Buprestidae, Elateroidea, and Byrrhoidea. Our findings will contribute to further studies on the identification, phylogeny, and evolution of leaf-mining jewel beetles.

Table 1. Molecular phylogenetic studies assessing the relationship of Buprestoidea with other Elateriformia superfamilies.

\begin{tabular}{|c|c|c|c|}
\hline $\begin{array}{l}\text { Taxonomic } \\
\text { Level }\end{array}$ & Elateriformia Groups Used * & Genes Used & References \\
\hline Coleoptera & $\begin{array}{c}4 \text { superfamilies }+ \text { Scirtoidea } \\
30 \text { families } \\
704 \text { species }\end{array}$ & $\begin{array}{c}\text { rRNA: } 18 \mathrm{~S}, 28 \mathrm{~S} \\
\text { mtDNA: } r r n l, \operatorname{cox} 1\left(\operatorname{cox} 1-5, \operatorname{cox} 1-3^{\prime}\right)\end{array}$ & [28] \\
\hline Coleoptera & $\begin{array}{c}4 \text { superfamilies }+ \text { Scirtoidea } \\
33 \text { families } \\
59 \text { species }\end{array}$ & $\begin{array}{c}\text { rRNA: } 18 S, 28 S \\
\text { nuclear: } A K, \text { AS, CAD, EF1a, } \\
\text { PEPCK, WG }\end{array}$ & [16] \\
\hline Coleoptera & $\begin{array}{c}4 \text { superfamilies } \\
7 \text { families } \\
34 \text { morphospecies }\end{array}$ & mtDNA: 1-13 PCGs & [31] \\
\hline Coleoptera & $\begin{array}{c}4 \text { superfamilies }+ \text { Scirtoidea } \\
29 \text { families } \\
564 \text { species }\end{array}$ & $\begin{array}{c}\text { rRNA: } 18 \mathrm{~S}, 28 \mathrm{~S} \\
\text { mtDNA: rrnl, cox1 } \\
\text { Transcriptomes: } 4220 \text { orthologs }\end{array}$ & [29] \\
\hline Coleoptera & $\begin{array}{c}4 \text { superfamilies }+ \text { Scirtoidea } \\
27 \text { families } \\
85 \text { species }\end{array}$ & nuclear: 95 PCGs & [17] \\
\hline Coleoptera & $\begin{array}{l}4 \text { superfamilies } \\
46 \text { subfamilies } \\
189 \text { species } \\
3 \text { superfamilies }\end{array}$ & $\begin{array}{c}\text { rRNA: } 18 \mathrm{~S} \\
\text { mtDNA: } r r n l, \operatorname{cox} 1\end{array}$ & [18] \\
\hline Coleoptera & $\begin{array}{l}8 \text { families } \\
12 \text { species }\end{array}$ & mtDNA: 12 or 13 PCGs & [25] \\
\hline Elateriformia & $\begin{array}{c}4 \text { superfamilies }+ \text { Scirtoidea } \\
28 \text { families } \\
112 \text { species }\end{array}$ & $\begin{array}{l}\text { rRNA: } 18 S, 28 S \\
\text { mtDNA: rrnl, } \operatorname{cox} 1\end{array}$ & [27] \\
\hline Elateriformia & $\begin{array}{c}4 \text { superfamilies } \\
17 \text { families } \\
27 \text { species }\end{array}$ & mtDNA: 12 PCGs or cob-nad6 & [26] \\
\hline Elateriformia & $\begin{array}{c}4 \text { superfamilies }+ \text { Scirtoidea } \\
31 \text { families } \\
488 \text { species }\end{array}$ & $\begin{array}{l}\text { rRNA: } 18 S, 28 S \\
\text { mtDNA: rrnl, cox1 }\end{array}$ & [30] \\
\hline Elateriformia & $\begin{array}{c}3 \text { superfamilies + Scirtoidea } \\
19 \text { species }\end{array}$ & mtDNA: all 13 PCGs & [23] \\
\hline Elateriformia & $\begin{array}{l}3 \text { superfamilies }+ \text { Scirtoidea } \\
18 \text { species }\end{array}$ & mtDNA: all 13 PCGs & [24] \\
\hline Elateriformia & $\begin{array}{c}3 \text { superfamilies }+ \text { Scirtoidea } \\
18 \text { families } \\
31 \text { species }\end{array}$ & $\begin{array}{c}\text { mtDNA: all } 13 \text { PCGs, rrnl, rrnlS, } 22 \\
\text { tRNA }\end{array}$ & this study \\
\hline
\end{tabular}




\section{Materials and Methods}

\subsection{Sampling and DNA Extraction}

Specimens of T. auricollis were collected on 18 August 2017, at Jiulianshan, Jiangxi Province, China (geographic coordinates: $24^{\circ} 34^{\prime} 11.99^{\prime \prime} \mathrm{N}, 114^{\circ} 26^{\prime} 24^{\prime \prime} \mathrm{E}$ ). Adults were stored in $100 \%$ ethanol at $-80{ }^{\circ} \mathrm{C}$. Samples were cataloged in the voucher collection of the Leafminer Group, School of Life Sciences, Gannan Normal University. T. auricollis specimens were sent to Shanghai Personal Biotechnology Co., Ltd. for mitogenome sequencing on 22 August 2017. Total genomic DNA was extracted from the head tissue of a single specimen using the CTAB method. DNA was preserved at $-20{ }^{\circ} \mathrm{C}$ and used for sequencing. The mitogenome sequence (MH638286) was submitted to the GenBank on 17 July 2018, as Submission2134492.txt.gz.

\subsection{Genome Sequencing and Analyses}

The total mitogenome of T. auricollis was obtained by next-generation sequencing using the whole-genome shotgun (WGS) strategy based on the Illumina MiSeq platform. Genomic DNA libraries were prepared using the Rapid Plus DNA Lib Prep Kit for Illumina. We then acquired and checked the raw data, including library insert fragments (approximately $400 \mathrm{bp}$ ); paired-end reads $(2 \times 251 \mathrm{bp})$, approximately 16,429 bp in length were obtained. The read numbers and total bases for T. auricollis are 5,331,476 bp and 1,418,148,881 bp, respectively, with approximately $485 \mathrm{bp}$ of missing sequence. The contigs and scaffolds of highly qualified sequences were determined using A5-miseq v20150522 [50] and SPAdesv3.9.0 [51]. Sequences with high sequencing depth were then compared with the NCBI nt library using BLASTN (BLAST v2.2.31+) [4] to select mitochondrial sequences resulting from different assemblies. MUMmer v3.1 [52] was used to perform collinear analysis, confirm the contig positions, and fill the gaps between contigs. Pilon v1.18 [53] was applied to correct the results and obtain the final mitochondrial sequences (*.fasta). The mitogenome was annotated on the MITOS web server (http://mitos.bioinf.uni-leipzig.de/index.py), and coding regions were manually verified by comparison against the NCBI database. All tRNA gene structures were predicted and determined by tRNA scan-SE or MITOS. Two rRNAs and all PCGs were annotated by alignment with homologous genes from another unpublished Trachys mitochondrial sequence (Table 2) using Geneious R11 [54]. Tandem repeats in the putative control region were assessed by Tandem Repeats Finder (http://tandem.bu.edu/trf/trf.html). MEGA version 7.0 [55] was employed to calculate the A $+T$ content, the nonsynonymous substitution rate to synonymous substitution rate $(\mathrm{Ka} / \mathrm{Ks})$ ratio, and the relative synonymous codon usage (RSCU) for PCG analysis. Genome organization and base composition, PCGs, codon usage, transfer RNAs, ribosomal RNAs, A + T-rich region, intergenic spacers, and overlapping regions of the mitogenome were compared between T. auricollis and T. troglodytiformis. The document 'linear_order.txt' obtained from the PhyloSuite was used to check gene rearrangement through the CREx website (http://pacosy.informatik.uni-leipzig.de/crex/) [56].

\subsection{Phylogenetic Analyses}

Phylogenetic analyses were performed based on the concatenated nucleotide sequences of all 13 PCGs, both rRNAs and 22 tRNAs for Elateriformia species, with Scirtoidea species used as outgroups. All available Buprestoidea species, Byrrhoidea species, Scirtoidea species, and Elateroidea families were covered. Because of the high abundance available mitogenomes for Elateroidea, we selected one representative species for each Elateroidea family. The representatives should be annotated as VERIFIED species, with the largest mitogenome sequence length. All mitogenomes chosen were complete or nearly complete in order to obtain all 37 genes. With seven buprestoid species, nine byrrhoid species, eight elateroid species, and five scirtoid species (Table 2), the number of species in each superfamily was similar and thus were balanced for topological construction.

The mitogenomes were obtained on 24 September 2019, from NCBI GenBank (Available online: http://www.ncbi.nlm.nih.gov). All mitogenome sequences were imported and standardized in 
PhyloSuite [57]. All PCGs, tRNAs, and rRNAs were extracted and aligned with MAFFT [58]. The concatenation of multiple alignments was performed, and a partition file was prepared; the partitioning scheme was obtained with PartitionFinder [59]. A greedy algorithm was adopted with the criterion of AICc to select the best-fit substitution model: GTR $+\mathrm{G}$ for the maximum likelihood (ML) tree and GTR + I + G for the Bayesian (BI) tree. ML tree was constructed with the IQ-Tree method [60] and BI tree with MrBayes methods [61]. Bootstrap analysis in IQ-Tree for each node was calculated using 1000 replications, with the MCMC setting in MrBayes for Generations for 2,000,000 times and a sampling frequency of 1000 replications. The phylogenetic trees were drawn using the software FigTree v1.4.3 [62]. 
Table 2. List of taxa used for the phylogenetic analysis in this study.

\begin{tabular}{|c|c|c|c|c|c|c|c|}
\hline Superfamily & Family & Species* & GenBank NO. & Size (bp) & Total $\mathrm{A}+\mathrm{T} \%$ & AT\% of all PCGs & References \\
\hline Buprestoidea & Buprestidae & Acmaeodera sp. & FJ613420 & 16,217 & 68.4 & 66.2 & [63] \\
\hline Buprestoidea & Buprestidae & Agrilus planipennis & КТ363854 & 15,942 & 71.9 & 70.1 & [25] \\
\hline Buprestoidea & Buprestidae & Agrilus sp. & JX412834 & 16,210 & 70.1 & 68.4 & [64] \\
\hline Buprestoidea & Buprestidae & Chrysochroa fulgidissima & NC012765 & 15,592 & 69.9 & 68.6 & [38] \\
\hline Buprestoidea & Buprestidae & Trachys auricollis & MH638268 & 16,429 & 71 & 69.3 & This study \\
\hline Buprestoidea & Buprestidae & Trachys troglodytiformis & KX087357 & 16,316 & 74.6 & 73.6 & [65] \\
\hline Buprestoidea & Buprestidae & Agrilinae sp. & MH789732 & 16,173 & 72.5 & 70.3 & [31] \\
\hline Byrrhoidea & Limnichidae & Byrrhinus sp. & JX412827 & 16,812 & 72.4 & 70.3 & {$[64]$} \\
\hline Byrrhoidea & Callirhipidae & Horatocera niponica & KX035160 & 16,107 & 75.5 & 73.4 & [66] \\
\hline Byrrhoidea & Dryopidae & Dryops ernesti & KX035147 & 15,672 & 73 & 71 & [67] \\
\hline Byrrhoidea & Dryopidae & Dryops luridus & KT876888 & 16,710 & 72.9 & 71.1 & [68] \\
\hline Byrrhoidea & Heteroceridae & Heterocerus parallelus & KX087297 & 15,845 & 74 & 72.5 & [65] \\
\hline Byrrhoidea & Limnichidae & Limnichidae sp. & JQ034416 & 14,388 & 74.6 & 73.5 & [26] \\
\hline Byrrhoidea & Psephenidae & Psephenidae sp. & KX035154 & 16,312 & 78.1 & 75.6 & [66] \\
\hline Byrrhoidea & Ptilodactylidae & Ptilodactylidae sp. & MH789727 & 15,991 & 74.8 & 72.1 & [31] \\
\hline Byrrhoidea & Chelonariidae & Chelonarium sp. & KX035150 & 15,095 & 75.6 & 72.9 & [67] \\
\hline Elateroidea & Cantharidae & Chauliognathus opacus & FJ613418 & 14,893 & 76.8 & 76.2 & [63] \\
\hline Elateroidea & Cerophytidae & Cerophytidae sp. & KX035161 & 15,741 & 80.4 & 79 & [67] \\
\hline Elateroidea & Elateridae & Limonius minutus & KX087306 & 16,727 & 76.7 & 74.8 & [65] \\
\hline Elateroidea & Lampyridae & Pyrocoelia rufa & AF452048 & 17,739 & 77.4 & 76.3 & [69] \\
\hline Elateroidea & Lycidae & Platerodrilus sp. & KU878647 & 16,394 & 76.9 & 76 & [70] \\
\hline Elateroidea & Phengodidae & Phrixothrix hirtus & KM923891 & 18,919 & 78 & 77.9 & [34] \\
\hline Elateroidea & Rhagophthalmidae & Rhagophthalmus lufengensis & NC010969 & 15,982 & 79.6 & 78.1 & [35] \\
\hline Elateroidea & Eucnemidae & Eucnemidae sp. & MH923241 & 16,170 & 78.3 & 76.2 & [31] \\
\hline Scirtoidea & Scirtidde & Cyphon sp. & NC011320 & 15,919 & 75.2 & 72.8 & [71] \\
\hline Scirtoidea & Scirtidde & Contacyphon variabilis & KT876886 & 15,901 & 75.9 & 71.1 & [68] \\
\hline Scirtoidea & Scirtidde & Elodes minuta & KX087288 & 17,043 & 76.8 & 72.8 & [65] \\
\hline Scirtoidea & Eucinetidae & Eucinetus haemorrhoidalis & NC036278 & 17,954 & 81 & 78.4 & [67] \\
\hline Scirtoidea & Scirtidae & Scirtes orbicularis & KX087343 & 13,944 & 76.5 & 75.4 & [65] \\
\hline
\end{tabular}

* The mitogenome sequence of a Scirtidae sp. (KT696212) was not included because it was close to Staphylinoidea species and far from other Scirtoidea species when blast-searched in NCBI. 


\section{Results and Discussion}

\subsection{Genome Organization and Base Composition}

The complete mitogenome of T. auricollis (GenBank: MH638286) is 16,429 bp in size, with an A + T content of $71.1 \%$. As with other beetle mitogenomes, the nucleotide composition of the T. auricollis mitogenome has an obvious $\mathrm{A}+\mathrm{T}$ bias. In general, the $\mathrm{A}+\mathrm{T}$ content of Buprestoidea is lower than that of other superfamilies (Table 2).

The mitogenome consists of 37 genes (13 PCGS, 22 tRNAs, and two rRNAs) and an A + T-rich region. Twenty-three genes (9 PCGs and $14 \mathrm{tRNAs}$ ) are located on the major strand (N-strand) and 14 genes (4 PCGs, 8 tRNAs, and 2 rRNAs) on the minor strand (J-strand) (Figure 2 and Table 3). The gene arrangement and orientation are similar to the typical beetle mitochondrial genome [38,72].

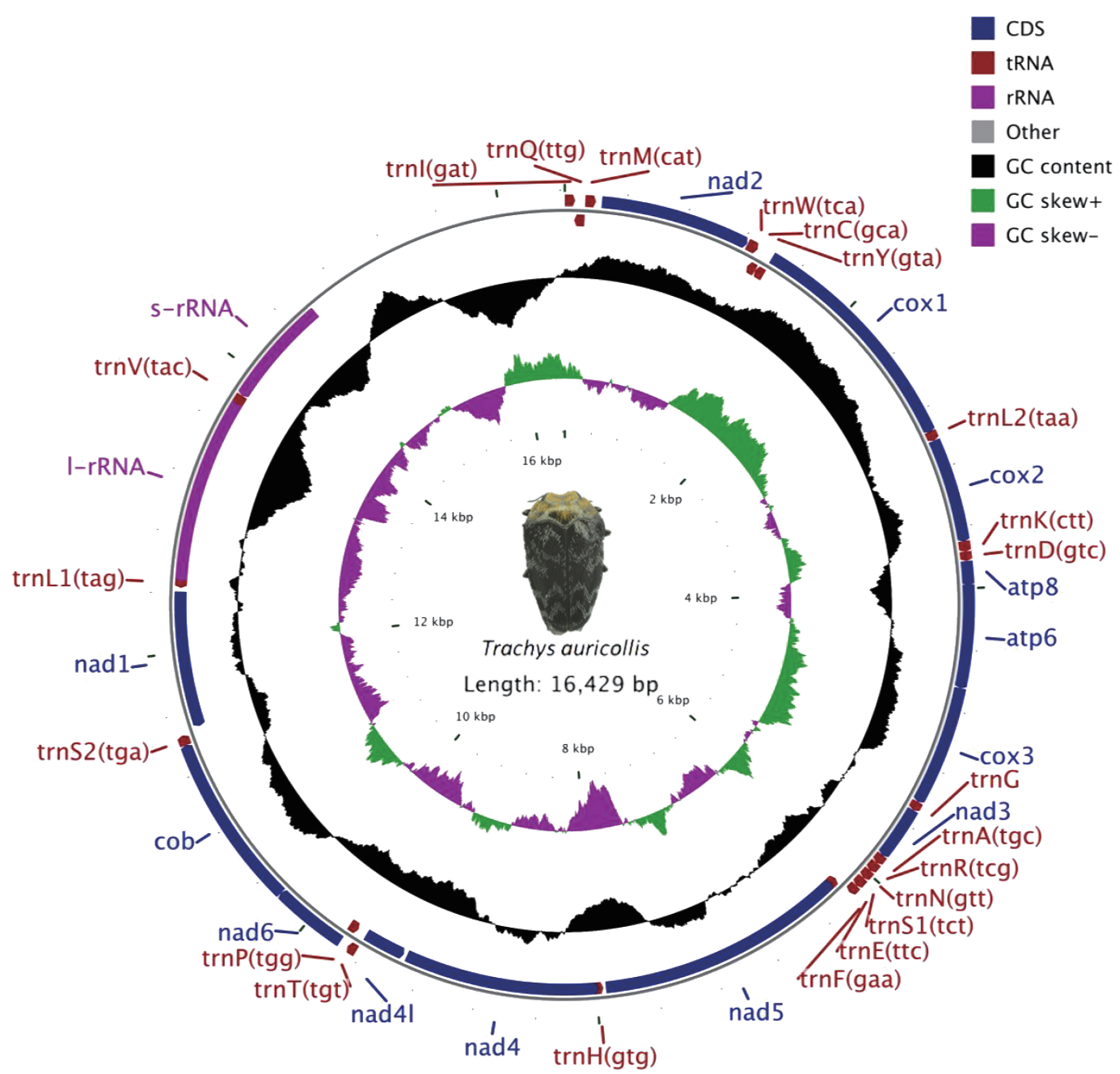

Figure 2. Circular map of the mitochondrial genome of T. auricollis. Genes outside the circle are transcribed in a clockwise direction, whereas those inside the circle are transcribed counterclockwise. Protein-coding genes (PCGs) are in blue, tRNA genes are in red, and rRNA genes are in purple. The second circle shows the GC content, and the third shows the GC skew. The GC content and GC skew are plotted as the deviation from the average value of the entire sequence. 
Table 3. Summary of the mitogenome of T. auricollis.

\begin{tabular}{|c|c|c|c|c|c|c|c|}
\hline Feature & Strand & Position & Length (bp) & Initiation Codon & Stop Codon & Anticodon & IGN \\
\hline $\operatorname{trnI}$ & $\mathrm{N}$ & $1-67$ & 67 & & & GTA & -3 \\
\hline $\operatorname{trnQ}$ & $\mathrm{J}$ & $65-133$ & 69 & & & TTG & \\
\hline $\operatorname{trnM}$ & $\mathrm{N}$ & $134-202$ & 69 & & & CAT & 39 \\
\hline $\operatorname{nad} 2$ & $\mathrm{~N}$ & $242-1222$ & 981 & ATG & TAA & & 5 \\
\hline $\operatorname{trnW}$ & $\mathrm{N}$ & $1228-1300$ & 73 & & & TCA & -8 \\
\hline $\operatorname{trnC}$ & $\mathrm{J}$ & $1293-1352$ & 60 & & & GCA & \\
\hline $\operatorname{trn} Y$ & $\mathrm{~J}$ & 1353-1417 & 65 & & & GTA & -8 \\
\hline $\operatorname{cox} 1$ & $\mathrm{~N}$ & $1410-2954$ & 1,545 & ATT & TAA & & -5 \\
\hline $\operatorname{trnL2}$ & $\mathrm{N}$ & 2950-3014 & 65 & & & TAA & \\
\hline $\operatorname{cox} 2$ & $\mathrm{~N}$ & $3015-3696$ & 682 & ATA & $\mathrm{T}(\mathrm{AA})$ & & -3 \\
\hline $\operatorname{trnK}$ & $\mathrm{N}$ & $3694-3764$ & 71 & & & CTT & -2 \\
\hline $\operatorname{trn} \mathrm{D}$ & $\mathrm{N}$ & $3763-3824$ & 62 & & & GTC & \\
\hline atp8 & $\mathrm{N}$ & $3825-3983$ & 159 & ATT & TAA & & -7 \\
\hline atp6 & $\mathrm{N}$ & $3977-4651$ & 675 & ATG & TAA & & -1 \\
\hline $\operatorname{cox} 3$ & $\mathrm{~N}$ & $4651-5437$ & 787 & ATG & $\mathrm{T}(\mathrm{AA})$ & & \\
\hline $\operatorname{trnG}$ & $\mathrm{N}$ & $5438-5499$ & 62 & & & TCC & \\
\hline nad3 & $\mathrm{N}$ & $5500-5883$ & 354 & ATA & TAG & & -2 \\
\hline $\operatorname{trn} \mathrm{A}$ & $\mathrm{N}$ & $5852-5914$ & 63 & & & TGC & -1 \\
\hline $\operatorname{trn} R$ & $\mathrm{~N}$ & 5914-5980 & 67 & & & TCG & -1 \\
\hline $\operatorname{trn} N$ & $\mathrm{~N}$ & $5980-6044$ & 65 & & & GTT & \\
\hline $\operatorname{trnS1}$ & $\mathrm{N}$ & $6045-6111$ & 67 & & & TCT & \\
\hline $\operatorname{trn} E$ & $\mathrm{~N}$ & $6112-6173$ & 62 & & & TTC & -1 \\
\hline $\operatorname{trnF}$ & $\mathrm{J}$ & $6173-6235$ & 63 & & & GAA & -20 \\
\hline nad5 & $\mathrm{J}$ & $6216-7934$ & 1,719 & ATT & TAG & & 18 \\
\hline $\operatorname{trnH}$ & $\mathrm{J}$ & 7953-8015 & 63 & & & GTG & -30 \\
\hline $\operatorname{nad} 4$ & $\mathrm{~J}$ & $7986-9321$ & 1,336 & ATG & $\mathrm{T}(\mathrm{AA})$ & & 23 \\
\hline nad41 & $\mathrm{J}$ & $9345-9632$ & 288 & ATG & TAA & & 2 \\
\hline $\operatorname{trnT}$ & $\mathrm{N}$ & $9635-9697$ & 63 & & & TGT & -1 \\
\hline $\operatorname{trn} \mathrm{P}$ & $\mathrm{J}$ & $9697-9762$ & 66 & & & TGG & -8 \\
\hline nad6 & $\mathrm{N}$ & 9755-10252 & 498 & ATT & TAA & & -1 \\
\hline $\mathrm{cob}$ & $\mathrm{N}$ & 10252-11397 & 1,146 & ATG & TAA & & -2 \\
\hline $\operatorname{trnS2}$ & $\mathrm{N}$ & 11396-11462 & 67 & & & TGA & 23 \\
\hline nad1 & $\mathrm{J}$ & 11486-12412 & 927 & ATT & TAA & & 25 \\
\hline $\operatorname{trnL1}$ & $\mathrm{J}$ & $12438-12502$ & 65 & & & TAG & -23 \\
\hline rrnL & $\mathrm{J}$ & 12480-13773 & 1,294 & & & & -19 \\
\hline $\operatorname{trnV}$ & $\mathrm{J}$ & 13755-13824 & 70 & & & TAC & \\
\hline $\operatorname{rrnS}$ & $\mathrm{J}$ & $13825-14582$ & 758 & & & & 1847 \\
\hline CR & - & $14582-16429$ & 1,846 & & & & \\
\hline \multicolumn{2}{|c|}{ Genome Size } & 16429 & & & & & 0 \\
\hline
\end{tabular}

$\mathrm{J}$ and $\mathrm{N}$ refer to the major and minor strands, respectively. Position numbers refer to positions on the majority strand. $\mathrm{CR}=$ the control region is also named the A + T-rich region. IGN = intergenic nucleotides.

The AT and GC skews of the complete mitogenome of T. auricollis were calculated, and the highest AT skew and GC skew values were found in the control region (CR) (0.04) and rrnL (-0.15). The AT skew and GC skew values of all PCGs in T. auricollis range from -0.35 (nad1) to 0.041 (atp8) and -0.31 (nad3) to 0.27 (nad5), respectively. Compared with all PCGs of T. troglodytiformis, some differences in the AT skew and GC skew values for cox1 and nad3 were observed (Table S1, Figure S1). The base composition might influence the values of AT skew and GC skew [73]. Related studies have suggested that for substitution models incorporating strand bias, mitochondrial replication might influence the GC skew in PCGs between the leading and lagging strands [74,75], and AT skew and GC skew have been determined to be a signal of transformation between the leading and lagging strands [72]. 


\subsection{Protein-Coding Genes}

All 13 PCGs of T. auricollis comprise 11,097 bp (Table 3), which can be translated into 3317 amino-acid-coding codons, excluding stop codons (33 bp). The $\mathrm{A}+\mathrm{T}$ content of all PCGs in the T. auricollis genome is $69.4 \%$, ranging from $63.9 \%$ (cox1) to $77.4 \%$ (atp8). Compared with T. troglodytiformis $(11,134 \mathrm{bp}), \mathrm{A}+\mathrm{T}$ bases account for approximately $73 \%$ of all PCGs, ranging from $68.8 \%$ (cox 1 ) to $80.4 \%$ (nad6) (Table S1, Figure S1). However, compared to most other beetle groups [25,38], low A + T contents are found in jewel beetles (Table 2).

All PCGs of T. auricollis initiate with the typical mitogenome ATN codon (Table 3); conversely, for T. troglodytiformis PCGs, twelve genes started with ATN, but nad1 initiates with TTG. Although most insect mitogenomes begin with ATN codons [73], the unusual initiation codon for the nad1 gene is also present in the mitogenomes of some other insects, such as Liriomyza trifolii (GTG) and Agonita chinensis (TTG) [32,41]. The cox1 gene begins with an ATN codon and is considered to be a characteristic of ancestral insects, although this still needs to be examined [71].

Complete stop codons (TAG and TAA) were found in 2 PCGs and 8 PCGs in T. auricollis, respectively. The remaining three genes appear to end with T or TA; two of these are adjacent to tRNAs, and one is located between nad4 and nad4l (Table 3). The incomplete stop codon may be converted into a proper TAA stop codon by RNA polyadenylation [76], which is common in animal genomes and can produce functional termination codons via polycistronic transcription cleavage and polyadenylation mechanisms [77]. The same stop codons are utilized in other PCGs, except nad5, of both Trachys species. The stop codon $\mathrm{T}$ located in nad5 of T. troglodytiformis is different from that of T. auricollis, which has a TAG stop codon. These differences between the two species might result from the 20 bp overlapping region between nad5 and trnF in T. auricollis; no such overlapping region exists in T. troglodytiformis.

$\mathrm{Ka} / \mathrm{Ks}$ ratios are a powerful approach for testing the neutral evolution model [78]; these ratios have been used to diagnose the form of sequence evolution [79]. Evaluation of the $\mathrm{Ka} / \mathrm{Ks}$ ratios for all PCGs of the two Trachys species revealed the atp8 and nad4l ratios to be larger than 1; atp8 has the highest evolutionary rate, and cox1 the lowest (Figure S2). The lowest A + T content in the cox1 gene might reflect its high conservation [72]. Indeed, cox1 shows the lowest $\mathrm{Ka} / \mathrm{Ks}$ value (i.e., lowest evolutionary rate) in nearly all animals (e.g., crustaceans [80-82], insects [83-87], mollusks [88-90], birds [91,92], and mammals [93]), indicating that this gene should be generally under the highest purification/selection pressure and functional constraints [80]. cox1 is thus the best DNA barcode for species identification and phylogenetic resolution in animals [89]. atp8 is one of the genes with the highest $\mathrm{Ka} / \mathrm{Ks}$ value (i.e., highest evolutionary rate) in many animals (e.g., crustaceans, [80-82], insects [84-87], mollusks [88-90], birds [91,92], and mammals [93]), indicating that atp8 should be generally under low purification/selection pressure and functional constraints, [80,88]. With a Ka/Ks value of atp 8 and nad $41>1$, the two genes would be considered representative of positive selection with some advantageous mutations, though negative selection tended to be indicated for the other genes [94].

\subsection{Codon Usage}

RSCU values for the PCGs in the mitochondrial genomes of the two Trachys species were analyzed, with most differing from 1 (frequency at equilibrium). The five most frequently used codons in T. auricollis are $\mathrm{UUA}(\mathrm{L}), \mathrm{CGA}(\mathrm{R}), \mathrm{AUA}(\mathrm{M}), \mathrm{AAA}(\mathrm{K})$, and $\mathrm{GCU}(\mathrm{A})$, and the first two most frequently used codons are consistent with those of T. troglodytiformis (Figure S3). Previous research has indicated that NNA and NNU (N represents A, T, C, G) codons can be used to express the frequency of A + T bias in PCGs [39].

\subsection{Transfer RNAs}

The total length of the T. auricollis tRNAs is $1,444 \mathrm{bp}$, with each tRNA gene ranging in size from $60 \mathrm{bp}(\operatorname{trnC})$ to $73 \mathrm{bp}$ (trnW) (Table 3). The A + T content of the $22 \mathrm{tRNAs}$ is $73.4 \%$, ranging from $82.3 \%$ 
(trnD) to $63.7 \%$ (trnQ) (Table S1). Compared with T. troglodytiformis, T. auricollis has a larger total length of tRNAs (1,450 bp) and a higher A + T content of tRNAs (76\%).

In the T. auricollis mitogenome, all 22 tRNA genes show typical cloverleaf structures, except for trnS1 (Figure S4). The same structures are found in T. troglodytiformis. For trnS1, the D-stem pairings in the dihydrouridine (DHU) arm are absent, as in many insect species (Figure S5). Although the trnS1 genes of both Trachys species are $67 \mathrm{bp}$ in size and both UCUs are located in the anticodon loop (AC-loop), apparent differences can be observed in their structure; the structure of UCUs in the anticodon loop might be considered to be indicative of those of more ancient insect groups [95]. The D-loop of the T. troglodytiformis trnS1 gene contains six bases more than that of T. auricollis, which is composed of the nonclassical base-pair A-U. For all other beetles, the D-loop, T-loop, and T-stem are easily mutated, whereas the AC-loop maintains high conservation [72].

\subsection{Ribosomal RNAs}

The boundaries of rRNA genes are delineated based on the alignment of the two leaf-mining jewel beetles. The large ribosomal RNA (rrnl) gene of T. auricollis is $1294 \mathrm{bp}$ in length, with an A + T content of $76.8 \%$; the small rRNA (rrns) gene is $758 \mathrm{bp}$, with an A + T content of $75.2 \%$ (Table S1). The two rRNA genes mapped between the trnL1 and trnV and the trnV and A + T-rich regions (Figure 2 and Table 3). Compared with other jewel beetles, the two rRNA genes of T. troglodytiformis and Chrysochroa fulgidissima have similar locations [38].

\subsection{A+T-Rich Region}

The A + T-rich region (CR) of T. auricollis is located between rrnS and the trnI-trnG-trnM gene cluster (Figure 2 and Table 3). The CR of T. auricollis includes six 72 bp tandem repeats (14,795-14,865 $\mathrm{bp}$ ), with approximately $10 \mathrm{bp}$ of poly-A stretches, with $16 \mathrm{bp}$ of poly-T stretches at the $3^{\prime}$ end of the CR. This region shows a $73.4 \% \mathrm{~A}+\mathrm{T}$ composition and a length of $1,847 \mathrm{bp}$, which is slightly longer than that of T. troglodytiformis (1728 bp) (Figure S6), with an A + T content of approximately $78.9 \%$. The A + T-rich region is the longest sequence in the mitogenomes of T. auricollis and T. troglodytiformis; however, the highest $\mathrm{A}+\mathrm{T}$ content among all genes is not found in the $\mathrm{A}+\mathrm{T}$-rich region but rather in the rrnL gene (Table S1). This A + T-rich region length is well within the range of those of other beetles, displaying remarkable variability and spanning from $201 \mathrm{bp}$ for Dryops sp. to 4,469 bp for Coccinella septempunctata (Coccinellidae) $[68,96]$.

In contrast, T. troglodytiformis harbors different repeated sequence regions $(15,861-15,902 \mathrm{bp})$ (Figure S7). Moreover, a conserved structural pattern was found in the two species. The size of the A + T-rich region might influence variation among beetle mitochondrial genomes [97], and the CR contains initiation sites for transcription and replication [98].

\subsection{Intergenic Spacer and Overlapping Regions}

Gene origin sites are almost immediately downstream of the 3' end of the previous gene; however, the overlap may occasionally occur at some initiation sites. The total length of the 20 overlapping regions in the T. auricollis mitogenome is $147 \mathrm{bp}$, ranging from $1 \mathrm{bp}$ to $30 \mathrm{bp}$ (Table 3). The first three longest overlap regions in the T. auricollis mitogenome are located between $\operatorname{trnH}$ and nad4 (30 bp), trnL1 and rrnL (23 bp), and trnF and nad5 (20 bp). In addition to the largest CR, $135 \mathrm{bp}$ of intergenic nucleotides [99] are present in 7 spacers, ranging from $2 \mathrm{bp}$ (nad4l and trnT) to $39 \mathrm{bp}$ (trnM and nad2), in T. auricollis.

In contrast, T. troglodytiformis harbors only 13 overlapping regions ranging from $1 \mathrm{bp}$ to $8 \mathrm{bp}$ and five intergenic regions ranging from $1 \mathrm{bp}$ to $26 \mathrm{bp}$. Additionally, these mitogenomes differ in their longest overlapping and intergenic regions. Some of the overlapping regions in T. auricollis consist of the intergenic regions present in the mitogenome of $T$. troglodytiformis, such as the intergenic regions of nad2-trnW (5 bp) and nad4-nad4l (23 bp), which are present at the overlapping regions in T. troglodytiformis at $1 \mathrm{bp}$ and $7 \mathrm{bp}$, respectively. 


\subsection{Phylogenetic Analyses}

Phylogenetic relationships were established based on the concatenated amino acid sequences of all PCGs, all rRNAs, and all tRNAs for all available Elateriformia species using Scirtoidea as the outgroup and applying both ML and BI methods (Table 2 and Figures 3 and 4). The log-likelihood (-LnL) value of the ML tree is 251,072, and the harmonic mean log-likelihood (-HMLi) value of the BI tree is 251,499 .

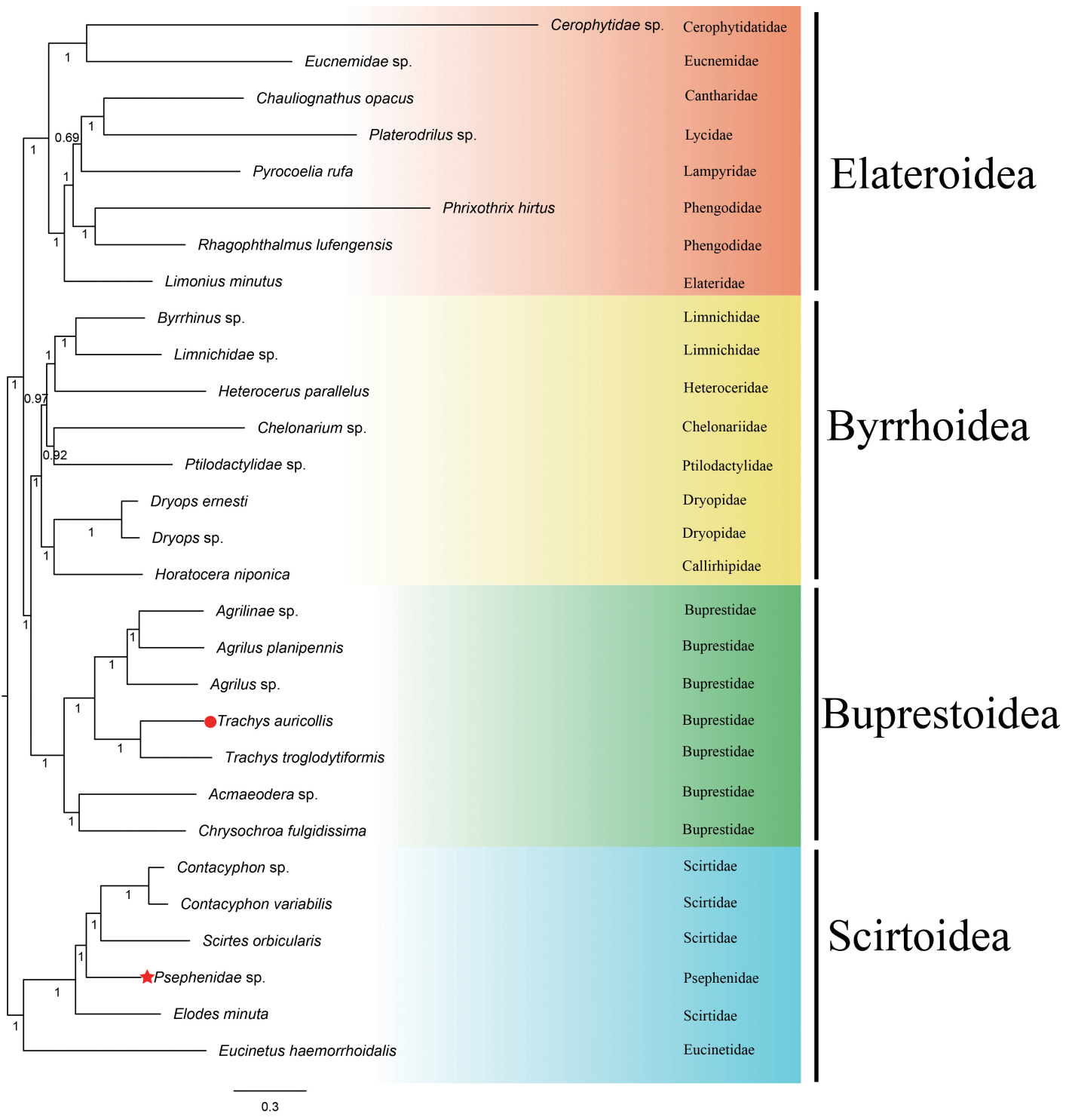

Figure 3. Maximum likelihood (ML) tree of evolutionary relationships between T. auricollis (solid red circle) and 27 other beetles based on all PCGs, all rRNAs, and all tRNAs. Red stars indicate inconsistent placement, as shown in Table 2. ML bootstrap values are shown at each node. The bar represents the number of substitutions per site. 


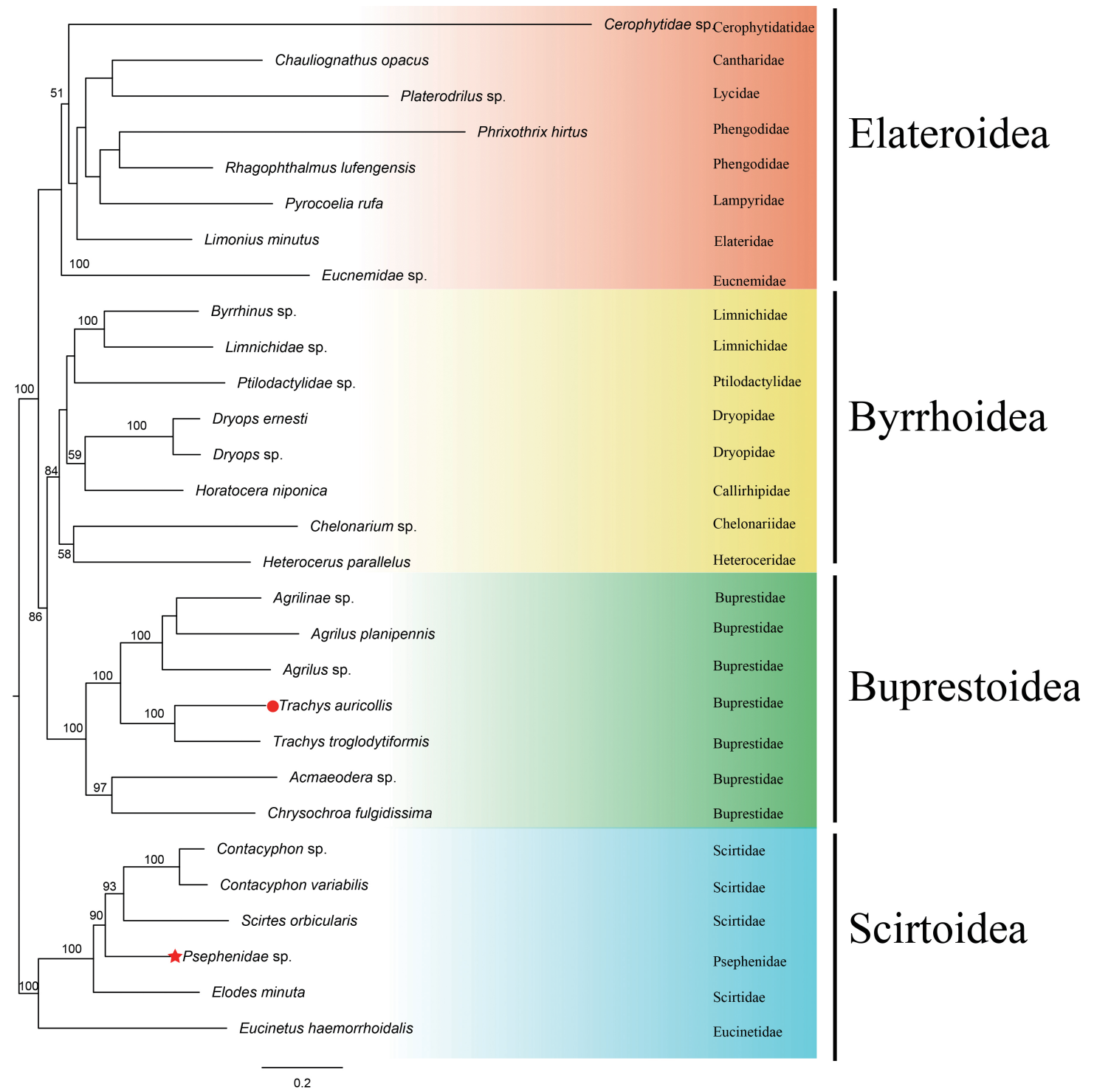

Figure 4. Bayesian (BI) tree of evolutionary relationships between T. auricollis (solid red circle) and 27 other beetles based on all PCGs, all rRNAs, and all tRNAs. Red stars indicate inconsistent placement, as shown in Table 2. Posterior probabilities are shown at each node. The bar represents the number of substitutions per site.

In this study, the topologies of both trees were stable at the superfamily level. Both trees show that Buprestoidea (Buprestidae only, without Schizopodidae) and Byrrhoidea (excluding Psephenidae) are reciprocally monophyletic groups; Elateroidea clusters as a sister to a clade of Byrrhoidea and Buprestoidea, but Psephenidae (of Byrrhoidea) is located within the Scirtoidea group. Our phylogenetic results support that Buprestoidea is a monophylum that is close to Byrrhoidea $[12,14,16,19,21,22,30]$; Buprestoidea and Byrrhoidea cluster within a clade sister to Elateroidea $[16,28,29,31]$, and the position of Psephenidae is undetermined [30].

There might be two possible ways to increase the accuracy of phylogenetic topological structure: one is to use more species, the other is to use more genes. The phylogenetic trees based on over 400 species all support that Buprestoidea and Byrrhoidea are very close, with Elateroidea located outside them (Figure 1 and Table 1) [28-30]. Our analysis with all 37 mitogenomic genes, including 13 PCGS, 22 tRNAs, and two rRNAs, agreed with this topology. That is, the topology based on either abundant species or abundant genes becomes consistent here. The inclusion of tRNAs might help to resolve the phylogeny of Coleoptera, just as in Diptera, Orthoptera, Neuropterida, and Lepidoptera [43,47-49]. 
However, due to the absence of complete mitogenomes for the Dascilloidea superfamily and several families in other superfamilies (such as Schizopodidae in Buprestoidea; Cneoglossidae, Elmidae, Eulichadidae, and Lutrochidae in Byrrhoidea; Artematopodidae, Brachypsectridae, Omalisidae, Omethidae, Podabrocephalidae, and Throscidae in Elateroidea; and Clambidae and Decliniidae in Scirtoidea), the placement of Buprestoidea in Elateriformia requires further verification. The Elateroidea appeared to have less support for internal nodes in the ML tree (Figure 3). Perhaps adding two representative species rather than one per family could help to stabilize the clustering pattern. However, we focus mainly on the relationships among different superfamilies in this study. Too many species in one superfamily might bias the topology. We hope that all the issues can be well solved when enough mitogenomes are accumulated for Elateriformia species in the future.

\section{Conclusions}

The mitogenome of the leaf-mining jewel beetle T. auricollis is the largest among the reported jewel beetle mitogenomes. The data obtained in this study reveal a typical closed-circular and double-stranded DNA molecular structure. The AT skew, GC skew, base composition, Ka/Ks ratio, and RSCU of the genes were calculated, and secondary cloverleaf structures for tRNA genes were predicted. Initiation and stop codons, tandem repeated units, and intergenic spacer and overlapping regions were analyzed. Our whole-mitogenome phylogenetic results support that Buprestoidea is close to Byrrhoidea and that Buprestoidea and Byrrhoidea cluster within a clade sister to Elateroidea; nonetheless, the position of Psephenidae remains undetermined. The inclusion of tRNAs might help to resolve the phylogeny of Coleoptera.

Supplementary Materials: The following are available online at http://www.mdpi.com/2073-4425/10/12/992/s1, Figure S1: The base composition of protein-coding genes and two rRNAs in the mitochondrial genomes of T. auricollis and T. troglodytiformis, Figure S2. Ka/Ks ratios of 13 protein-coding genes. Ka is the nonsynonymous substitution rate, and Ks is the synonymous substitution rate, Figure S3. Relative synonymous codon usage (RSCU) for protein-coding genes of T. auricollis and T. troglodytiformis mitochondrial genomes. Codon families are provided on the x-axis, Figure S4. Predicted secondary structures of the 22 typical tRNA genes of the T. auricollis mitochondrial genome, Figure S5. Predicted secondary cloverleaf structure for the trnS1 genes of T. auricollis and T. troglodytiformis, Figure S6. Alignment of the conserved structural elements of the control regions (CRs) of T. auricollis and T. troglodytiformis, Figure S7. Partial A + T-rich regions of T. auricollis and T. troglodytiformis. The underlined sequences are perfectly repeated sequences in the A + T-rich region. The position refers to the length of the first repeated sequence, Table S1: Length, A + T content (\%), AT skew, and GC skew for T. auricollis and T. troglodytiformis.

Author Contributions: Conceptualization, X.D.; methodology, L.X. and S.Z.; software, L.X., S.Z. and C.L.; validation, Q.G.; formal analysis, L.X., S.Z., C.L., Q.G. and X.D.; investigation, L.X., C.L. and J.X.; resources, X.D. and J.W.; data curation, L.X., S.Z., C.L., J.X. and J.W.; writing-original draft preparation, L.X. and S.Z.; writing-review and editing, L.X., S.Z., C.L., Q.G., J.X., X.D. and J.W.; visualization, L.X. and S.Z.; supervision, X.D. and J.W.; project administration, X.D.; funding acquisition, Q.G., J.X. and X.D.

Funding: This work was funded by the National Natural Science Foundation of China (31760173, 41971059, 41861007 and 31702069), the Natural Science Foundation of Jiangxi Province (20171BAB204023) and the Innovation Team Project of Gannan Normal University.

Acknowledgments: We express our appreciation to every member of the Leafminer Group for help in sample collection and data analysis. We also thank Shanghai Personal Biotechnology Co., Ltd. for mitogenome sequencing and American Journal Experts (AJE) for English-language editing (http://www.aje.com/r/NRW49). The editors and reviewers of Genes and one other journal (which rejected our manuscript) provided insightful comments that helped us improve the manuscript substantially.

Conflicts of Interest: The authors declare no conflict of interest.

\section{References}

1. Evans, A.M.; Mckenna, D.D.; Bellamy, C.L.; Farrell, B.D. Large-scale molecular phylogeny of metallic wood-boring beetles (Coleoptera: Buprestoidea) provides new insights into relationships and reveals multiple evolutionary origins of the larval leaf-mining habit. Syst. Entomol. 2015, 40, 385-400. [CrossRef]

2. Pan, X.; Chang, H.; Ren, D.; Shih, C. The first fossil buprestids from the Middle Jurassic Jiulongshan Formation of China (Coleoptera: Buprestidae). Zootaxa 2011, 2745, 53-62. [CrossRef] 
3. Bellamy, C.L. A World Catalogue and Bibliography of the Jewel Beetles (Coleoptera: Buprestoidea); Pensoft Publishers: Sofia-Moscow, Russia, 2008.

4. NCBI Resource Coordinators. Database resources of the National Center for Biotechnology Information. Nucl. Acids Res. 2018, 35, 5-12. [CrossRef]

5. Ross, H.; Arnet, J.; Thomas, M.C.; Skelley, P.E.; Frank, H.J. American Beetles, Volume II: Polyphaga: Scarabaeoidea through Curculionoidea; CRC Press: Boca Raton, FL, USA, 2002; p. 861.

6. Hering, E.M. Biology of the Leaf Miners; Dr. W. Junk: The Hague, The Netherlands, 1951; p. 420.

7. Akiyama, K.; Omomo, S. The Buprestid Beetles of the World; Gekkan-Mushi: Tokyo, Japan, 2000; p. 330.

8. Xiao, L.; Dai, X.; Wang, J. Research progress on leaf-mining jewel beetles. North. Hortic. 2017, 15, $162-167$. [CrossRef]

9. Imai, K.; Miura, K.; Iida, H.; Reardon, R.; Fujisaki, K. Herbivorous insect fauna of Kudzu, Pueraria montana (Leguminosae), in Japan. Fla. Entomol. 2010, 93, 454-456.

10. Forseth, I.N.; Innis, A.F. Kudzu (Pueraria montana): History, physiology, and ecology combine to make a major ecosystem threat. Crit. Rev. Plant Sci. 2004, 23, 401-413. [CrossRef]

11. Beutel, R.G.; Leschen, R.A.B. Coleoptera, Beetles. Volume 1: Morphology and Systematics; De Gruyter: Berlin, Germany, 2016; p. 812.

12. Lawrence, J.F.; Ślipiński, A.; Seago, A.E.; Thayer, M.K.; Newton, A.F.; Marvaldi, A.E. Phylogeny of the Coleoptera based on morphological characters of adults and larvae. Ann. Zool. 2011, 61, 1-217. [CrossRef]

13. Xu, H. Study on Systematics of Coraebini from China (Coleoptera: Buprestoidea: Agrilinae); University of Chinese Academy of Sciences: Beijing, China, 2013.

14. Lawrence, J.F. Families and sub-families of Coleoptera (with selected genera, notes, references and data on family-group names). In Biology, Phylogeny, and Classification of Coleoptera. Papers Celebrating the 80th Birthday of Roy A. Crowson; Muzeum i Instytut Zoologii PAN: Warszawa, Poland, 1995; pp. 779-1083.

15. Nelson, G.; Bellamy, C. A revision and phylogenetic re-evaluation of the family Schizopodidae (Coleoptera, Buprestoidea). J. Nat. Hist. 1991, 25, 985-1026. [CrossRef]

16. McKenna, D.D.; Wild, A.L.; Kanda, K.; Bellamy, C.L.; Beutel, R.G.; Caterino, M.S.; Farnum, C.W.; Hawks, D.C.; Ivie, M.A.; Jameson, M.L.; et al. The beetle tree of life reveals that Coleoptera survived end-Permian mass extinction to diversify during the Cretaceous terrestrial revolution. Syst. Entomol. 2015, 40, 835-880. [CrossRef]

17. Zhang, S.; Che, L.; Li, Y.; Liang, D.; Pang, H.; Ślipiński, A.; Zhang, P. Evolutionary history of Coleoptera revealed by extensive sampling of genes and species. Nat. Commun. 2018, 9, 1-11. [CrossRef]

18. Hunt, T.; Bergsten, J.; Levkanicova, Z.; Papadopoulou, A.; John, O.S.; Wild, R.; Hammond, P.M.; Ahrens, D.; Balke, M.; Caterino, M.S.; et al. A comprehensive phylogeny of beetles reveals the evolutionary origins of a superradiation. Science 2007, 318, 1913-1916. [CrossRef]

19. Crowson, R. On the dryopoid affinities of Buprestidae. Coleopt. Bull. 1982, 36, 22-25.

20. Bouchard, P.; Bousquet, Y.; Davies, A.; Alonso-Zarazaga, M.; Lawrence, J.; Lyal, C.; Newton, A.; Reid, C.; Schmitt, M.; Slipinski, A.; et al. Family-group names in Coleoptera (Insecta). ZooKeys 2011, 88, 1-972. [CrossRef]

21. Lawrence, J.F. Rhinorhipidae, a new beetle family from Australia, with comments on the phylogeny of the Elateriformia. Invertebr. Syst. 1988, 2, 1-53. [CrossRef]

22. Costa, C.; Vanin, S.A.; Ide, S. Systematics and bionomics of Cneoglossidae with a cladistic analysis of Byrrhoidea. Arq. Zool. 1999, 35, 231-300. [CrossRef]

23. Cao, L.; Wang, X. The complete mitochondrial genome of the jewel beetle Trachys variolaris (Coleoptera: Buprestidae). Mitochondrial DNA Part B 2019, 4, 3042-3043. [CrossRef]

24. Cao, L.; Wang, X. The complete mitochondrial genome of the jewel beetle Coraebus cavifrons (Coleoptera: Buprestidae). Mitochondrial DNA Part B 2019, 4, 2407-2408. [CrossRef]

25. Duan, J.; Quan, G.; Mittapalli, O.; Cusson, M.; Krell, P.J.; Doucet, D. The complete mitogenome of the Emerald Ash Borer (EAB), Agrilus planipennis (Insecta: Coleoptera: Buprestidae). Mitochondrial DNA Part B 2017, 2, 134-135. [CrossRef]

26. Timmermans, M.J.; Vogler, A.P. Phylogenetically informative rearrangements in mitochondrial genomes of Coleoptera, and monophyly of aquatic elateriform beetle (Dryopoidea). Mol. Phylogenet. Evol. 2012, 63, 299-304. [CrossRef] 
27. Bocakova, M.; Bocak, L.; Hunt, T.; Teraväinen, M.; Vogler, A.P. Molecular phylogenetics of Elateriformia (Coleoptera): Evolution of bioluminescence and neoteny. Cladistics 2007, 23, 477-496. [CrossRef]

28. Bocak, L.; Barton, C.; Crampton-Platt, A.; Chesters, D.; Ahrens, D.; Vogler, A.P. Building the Coleoptera tree-of-life for $>8000$ species: Composition of public DNA data and fit with Linnaean classification. Syst. Entomol. 2014, 39, 97-110. [CrossRef]

29. Kusy, D.; Motyka, M.; Andújar, C.; Bocek, M. Genome sequencing of Rhinorhipus Lawrence exposes an early branch of the Coleoptera. Front. Zool. 2018, 15, 1-25. [CrossRef]

30. Kundrata, R.; Jäch, M.A.; Bocak, L. Molecular phylogeny of the Byrrhoidea-Buprestoidea complex (Coleoptera: Elateriformia). Zool. Scr. 2017, 46, 1-15. [CrossRef]

31. Crampton-Platt, A.; Timmermans, M.J.; Gimmel, M.L.; Kutty, S.N.; Cockerill, T.D.; Vun Khen, C.; Vogler, A.P. Soup to tree: The phylogeny of beetles inferred by mitochondrial metagenomics of a Bornean rainforest sample. Mol. Biol. Evol. 2015, 32, 2302-2316. [CrossRef]

32. Yang, F.; Du, Y.; Cao, J.; Huang, F. Analysis of three leafminers' complete mitochondrial genomes. Gene 2013, 529, 1-6. [CrossRef]

33. Chen, Z.; Du, Y. First mitochondrial genome from Nemouridae (Plecoptera) reveals novel features of the elongated control region and phylogenetic implications. Int. J. Mol. Sci. 2017, 18, 996. [CrossRef]

34. Amaral, D.T.; Mitani, Y.; Ohmiya, Y.; Viviani, V.R. Organization and comparative analysis of the mitochondrial genomes of bioluminescent Elateroidea (Coleoptera: Polyphaga). Gene 2016, 586, 254-262. [CrossRef]

35. Li, X.; Ogoh, K.; Ohba, N.; Liang, X.; Ohmiya, Y. Mitochondrial genomes of two luminous beetles, Rhagophthalmus lufengensis and R. ohbai (Arthropoda, Insecta, Coleoptera). Gene 2007, 392, 196-205. [CrossRef]

36. Arnoldi, F.G.; Ogoh, K.; Ohmiya, Y.; Viviani, V.R. Mitochondrial genome sequence of the Brazilian luminescent click beetle Pyrophorus divergens (Coleoptera: Elateridae): Mitochondrial genes utility to investigate the evolutionary history of Coleoptera and its bioluminescence. Gene 2007, 405, 1-9. [CrossRef]

37. Boore, J.L. Animal mitochondrial genomes. Nucl. Acids Res. 1999, 27, 1767-1780. [CrossRef]

38. Hong, M.Y.; Jeong, H.C.; Kim, M.J.; Jeong, H.U.; Lee, S.H.; Kim, I. Complete mitogenome sequence of the jewel beetle, Chrysochroa fulgidissima (Coleoptera: Buprestidae). Mitochondrial DNA 2009, 20, 46-60. [CrossRef]

39. Li, W.; Wang, Z.; Che, Y. The complete mitogenome of the wood-feeding Cockroach Cryptocercus meridianus (Blattodea: Cryptocercidae) and its phylogenetic relationship among Cockroach families. Int. J. Mol. Sci. 2017, 18, 2397. [CrossRef]

40. Du, C.; He, S.; Song, X.; Liao, Q.; Zhang, X.; Yue, B. The complete mitochondrial genome of Epicauta chinensis (Coleoptera: Meloidae) and phylogenetic analysis among Coleopteran insects. Gene 2016, 578, 274-280. [CrossRef]

41. Guo, Q.; Xu, J.; Liao, C.; Dai, X.; Jiang, X. Complete mitochondrial genome of a leaf-mining beetle, Agonita chinensis Weise (Coleoptera: Chrysomelidae). Mitochondrial DNA Part B 2017, 2, 532-533. [CrossRef]

42. Kim, H.; Lee, S. A molecular phylogeny of the tribe Aphidini (Insecta: Hemiptera: Aphididae) based on the mitochondrial tRNA/COII, 12S/16S and the nuclear EF1 $\alpha$ genes. Syst. Entomol. 2008, 33, 711-721. [CrossRef]

43. Yang, X.; Cameron, S.L.; Lees, D.C.; Xue, D.; Han, H. A mitochondrial genome phylogeny of owlet moths (Lepidoptera: Noctuoidea), and examination of the utility of mitochondrial genomes for lepidopteran phylogenetics. Mol. Phylogenet. Evol. 2015, 85, 230-237. [CrossRef]

44. Widmann, J.; Harris, J.K.; Lozupone, C.; Wolfson, A.; Knight, R. Stable tRNA-based phylogenies using only 76 nucleotides. RNA 2010, 16, 1469-1477. [CrossRef]

45. Kumazawa, Y.; Nishida, M. Sequence evolution of mitochondrial tRNA genes and deep-branch animal phylogenetics. J. Mol. Evol. 1993, 37, 380-398. [CrossRef]

46. Kumazawa, Y.; Nishida, M. Variations in mitochondrial tRNA gene organization of reptiles as phylogenetic markers. Mol. Biol. Evol. 1995, 12, 759-772.

47. Cameron, S.L.; Lambkin, C.L.; Barker, S.C.; Whiting, M.F. A mitochondrial genome phylogeny of Diptera: Whole genome sequence data accurately resolve relationships over broad timescales with high precision. Syst. Entomol. 2007, 32, 40-59. [CrossRef]

48. Cameron, S.L.; Sullivan, J.; Song, H.; Miller, K.B.; Whiting, M.F. A mitochondrial genome phylogeny of the Neuropterida (lace-wings, alderflies and snakeflies) and their relationship to the other holometabolous insect orders. Zool. Scr. 2009, 38, 575-590. [CrossRef] 
49. Fenn, J.D.; Song, H.; Cameron, S.L.; Whiting, M.F. A preliminary mitochondrial genome phylogeny of Orthoptera (Insecta) and approaches to maximizing phylogenetic signal found within mitochondrial genome data. Mol. Phylogenet. Evol. 2008, 49, 59-68. [CrossRef] [PubMed]

50. Coil, D.; Jospin, G.; Darling, A.E. A5-miseq: An updated pipeline to assemble microbial genomes from Illumina MiSeq data. Genomics 2014, 31, 587-589. [CrossRef] [PubMed]

51. Bankevich, A.; Nurk, S.; Antipov, D.; Gurevich, A.A.; Dvorkin, M.; Kulikov, A.S.; Lesin, V.M.; Nikolenko, S.I.; Pham, S.; Prjibelski, A.D.; et al. SPAdes: A new genome assembly algorithm and its applications to single-cell sequencing. J. Comput. Biol. 2012, 19, 455-477. [CrossRef]

52. Kurtz, S.; Phillippy, A.; Delcher, A.L.; Smoot, M.; Shumway, M.; Antonescu, C.; Salzberg, S.L. Versatile and open software for comparing large genomes. Genome Biol. 2004, 5, R12. [CrossRef]

53. Walker, B.J.; Abeel, T.; Shea, T.; Priest, M.; Abouelliel, A.; Sakthikumar, S.; Cuomo, C.A.; Zeng, Q.; Wortman, J.; Young, S.K.; et al. Pilon: An integrated tool for comprehensive microbial variant detection and genome assembly improvement. PLoS ONE 2014, 9, e112963. [CrossRef]

54. Kearse, M.; Moir, R.; Wilson, A. Geneious basic. Bioinformatics 2012, 28, 1647-1649. [CrossRef]

55. Kumar, S.; Stecher, G.; Tamura, K. MEGA7: Molecular evolutionary genetics analysis version 7.0 for bigger datasets. Mol. Biol. Evol. 2016, 33, 1870-1874. [CrossRef]

56. Bernt, M.; Merkle, D.; Ramsch, K.; Fritzsch, G.; Perseke, M.; Bernhard, D.; Schlegel, M.; Stadler, P.F.; Middendorf, M. CREx: Inferring genomic rearrangements based on common intervals. Bioinformatics 2007, 23, 2957-2958. [CrossRef]

57. Zhang, D.; Gao, F.; Li, W.X.; Jakovlić, I.; Zou, H.; Zhang, J.; Wang, G.T. PhyloSuite: An integrated and scalable desktop platform for streamlined molecular sequence data management and evolutionary phylogenetics studies. Mol. Ecol. Resour. 2018, 489088. [CrossRef]

58. Katoh, K.; Standley, D.M. MAFFT multiple sequence alignment software version 7: Improvements in performance and usability. Mol. Biol. Evol. 2013, 30, 772-780. [CrossRef]

59. Lanfear, R.; Frandsen, P.; Wright, A.; Senfeld, T.; Calcott, B. PartitionFinder 2: New methods for selecting partitioned models of evolution for molecular and morphological phylogenetic analyses. Mol. Biol. Evol. 2017, 34, 772-773. [CrossRef] [PubMed]

60. Nguyen, L.-T.; Schmidt, H.A.; von Haeseler, A.; Minh, B.Q. IQ-TREE: A fast and effective stochastic algorithm for estimating maximum-likelihood phylogenies. Mol. Biol. Evol. 2014, 32, 268-274. [CrossRef] [PubMed]

61. Ronquist, F.; Teslenko, M.; Van Der Mark, P.; Ayres, D.L.; Darling, A.; Höhna, S.; Larget, B.; Liu, L.; Suchard, M.A.; Huelsenbeck, J.P. MrBayes 3.2: Efficient Bayesian phylogenetic inference and model choice across a large model space. Syst. Biol. 2012, 61, 539-542. [CrossRef]

62. Rambaut, A. FigTree 1.4.3 Software; Institute of Evolutionary Biology, University of Edinburgh: Edinburgh, Scotland, UK, 2016.

63. Sheffield, N.C.; Song, H.; Cameron, S.L.; Whiting, M.F. Nonstationary evolution and compositional heterogeneity in beetle mitochondrial phylogenomics. Soc. Syst. Biol. 2009, 58, 381-394. [CrossRef]

64. Timmermans, M.J.T.N.; Lim, J.; Dodsworth, S.; Haran, J.; Ahrens, D.; Bocak, L.; London, A.; Culverwell, L.; Vogler, A.P. Mitogenomics of the Coleoptera under dense taxon sampling. Unpublished.

65. Hunter, A.; Moriniere, J.; Tang, P.; Linard, B.; Crampton-Platt, A.; Vogler, A.P. Mitochondria of beetle species. Unpublished.

66. Linard, B.; Andujar, C.; Arribas, P.; Vogler, A.P. Direct Submission to GenBank. Unpublished.

67. Linard, B.; Andujar, C.; Arribas, P.; Vogler, A.P. Mitochondria of unsequenced beetle families. Unpublished.

68. Linard, B.; Arribas, P.; Andujar, C.; Crampton-Platt, A.; Vogler, A.P. Lessons from genome skimming of arthropod-preserving ethanol. Mol. Ecol. Resour. 2016, 16, 1365-1377. [CrossRef]

69. Bae, J.S.; Kim, I.; Sohn, H.D.; Jin, B.R. The mitochondrial genome of the firefly, Pyrocoelia rufa: Complete DNA sequence, genome organization, and phylogenetic analysis with other insects. Mol. Phylogenet. Evol. 2004, 32, 978-985. [CrossRef]

70. Uribe, J.E.; Gutierrez-Rodriguez, J. The complete mitogenome of the trilobite beetle, Platerodrilus sp. (Elateroidea: Lycidae). Mitochondrial DNA B Resour. 2016, 1, 658-659. [CrossRef]

71. Sheffield, N.C.; Song, H.; Cameron, S.L.; Whiting, M.F. A comparative analysis of mitochondrial genomes in coleoptera (Arthropoda: Insecta) and genome descriptions of six new beetles. Mol. Biol. Evol. 2008, 25, 2499-2509. [CrossRef] 
72. Nie, R.; Yang, X. Research progress in mitochondrial genomes of Coleoptera. Acta Biochim. Biophys. Sin. 2014, 57, 860-868.

73. Ma, C.; Liu, C.; Yang, P.; Kang, L. The complete mitochondrial genomes of two band-winged grasshoppers, Gastrimargus marmoratus and Oedaleus asiaticus. BMC Genom. 2009, 10, 156. [CrossRef] [PubMed]

74. Marín, A.; Xia, X. GC skew in protein-coding genes between the leading and lagging strands in bacterial genomes: New substitution models incorporating strand bias. J. Theor. Biol. 2008, 253, 508-513. [CrossRef] [PubMed]

75. Sahyoun, A.H.; Bernt, M.; Stadler, P.F.; Toutb, K. GC skew and mitochondrial origins of replication. Mitochondrion 2014, 17, 56-66. [CrossRef] [PubMed]

76. Nardi, F.; Carapelli, A.; Fanciulli, P.P.; Dallai, R.; Frati, F. The complete mitochondrial DNA sequence of the basal hexapod Tetrodontophora bielanensis: Evidence for heteroplasmy and tRNA translocations. Mol. Biol. Evol. 2001, 18, 1293-1304. [CrossRef]

77. Chen, S.C.; Wang, X.Q.; Li, P.W.; Hu, X.; Wang, J.J.; Peng, P. The complete mitochondrial genome of Aleurocanthus camelliae: Insights into gene arrangement and genome organization within the family Aleyrodidae. Int. J. Mol. Sci. 2016, 17, 1843. [CrossRef]

78. Yang, Z.; Bielawski, J.P. Statistical methods for detecting molecular adaptation. Trends Ecol. Evol. 2000, 15, 496-503. [CrossRef]

79. Hurst, L.D. The Ka/Ks ratio: Diagnosing the form of sequence evolution. Trends Genet. 2002, 18, $486-487$. [CrossRef]

80. Shen, X.; Li, X.; Sha, Z.; Yan, B.; Xu, Q. Complete mitochondrial genome of the Japanese snapping shrimp Alpheus japonicus (Crustacea: Decapoda: Caridea): Gene rearrangement and phylogeny within Caridea. Sci. China Life Sci. 2012, 55, 591-598. [CrossRef]

81. Shen, X.; Wang, H.; Wang, M.; Liu, B. The complete mitochondrial genome sequence of Euphausia pacifica (Malacostraca: Euphausiacea) reveals a novel gene order and unusual tandem repeats. Genome 2011, 54, 911-922. [CrossRef]

82. Zhang, H.; Luo, Q.; Sun, J.; Liu, F.; Wu, G.; Yu, J.; Wang, W. Mitochondrial genome sequences of Artemia tibetiana and Artemia urmiana: Assessing molecular changes for high plateau adaptation. Sci. China Life Sci. 2013, 56, 440-452. [CrossRef]

83. Liu, Y.-Q.; Li, Y.-P.; Wang, H.; Xia, R.-X.; Chai, C.-L.; Pan, M.-H.; Lu, C.; Xiang, Z.-H. The complete mitochondrial genome of the wild type of Antheraea pernyi (Lepidoptera: Saturniidae). Ann. Entomol. Soc. Am. 2012, 105, 498-505. [CrossRef]

84. Li, N.; Hu, G.-L.; Hua, B.-Z. Complete mitochondrial genomes of Bittacus strigosus and Panorpa debilis and genomic comparisons of Mecoptera. Int. J. Biol. Macromol. 2019, 140, 672-681. [CrossRef] [PubMed]

85. Gong, R.; Guo, X.; Ma, J.; Song, X.; Shen, Y.; Geng, F.; Price, M.; Zhang, X.; Yue, B. Complete mitochondrial genome of Periplaneta brunnea (Blattodea: Blattidae) and phylogenetic analyses within Blattodea. J. Asia Pac. Entomol. 2018, 21, 885-895. [CrossRef]

86. Oliveira, D.C.S.G.; Raychoudhury, R.; Lavrov, D.V.; Werren, J.H. Rapidly evolving mitochondrial genome and directional selection in mitochondrial genes in the parasitic wasp Nasonia (Hymenoptera: Pteromalidae). Mol. Biol. Evol. 2008, 25, 2167-2180. [CrossRef]

87. Li, H.; Liu, H.; Song, F.; Shi, A.; Zhou, X.; Cai, W. Comparative mitogenomic analysis of damsel bugs representing three tribes in the family Nabidae (Insecta: Hemiptera). PLoS ONE 2012, 7, e45925. [CrossRef]

88. Śmietanka, B.; Burzyński, A.; Wenne, R. Comparative genomics of marine mussels (Mytilus spp.) gender associated mtDNA: Rapidly evolving atp8. J. Mol. Evol. 2010, 71, 385-400. [CrossRef]

89. Arquez, M.; Colgan, D.; Castro, L.R. Sequence and comparison of mitochondrial genomes in the genus Nerita (Gastropoda: Neritimorpha: Neritidae) and phylogenetic considerations among gastropods. Mar. Genom. 2014, 15, 45-54. [CrossRef]

90. Gao, B.; Peng, C.; Chen, Q.; Zhang, J.; Shi, Q. Mitochondrial genome sequencing of a vermivorous cone snail Conus quercinus supports the correlative analysis between phylogenetic relationships and dietary types of Conus species. PLoS ONE 2018, 13, e0193053. [CrossRef]

91. Li, X.; Huang, Y.; Lei, F. Comparative mitochondrial genomics and phylogenetic relationships of the Crossoptilon species (Phasianidae, Galliformes). BMC Genom. 2015, 16, 42. [CrossRef] 
92. Jiang, F.; Miao, Y.; Liang, W.; Ye, H.; Liu, H.; Liu, B. The complete mitochondrial genomes of the whistling duck (Dendrocygna javanica) and black swan (Cygnus atratus): Dating evolutionary divergence in Galloanserae. Mol. Biol. Rep. 2010, 37, 3001-3015. [CrossRef]

93. Wei,H.; Li, F.; Wang, X.; Wang, Q.; Chen, G.; Zong, H.; Chen, S. The characterization of complete mitochondrial genome and phylogenetic relationship within Rattus genus (Rodentia: Muridae). Biochem. Syst. Ecol. 2017, 71, 179-186. [CrossRef]

94. Li, J.; Zhang, Z.; Vang, S.; Yu, J.; Wong, G.K.; Wang, J. Correlation between Ka/Ks and Ks is related to substitution model and evolutionary lineage. J. Mol. Evol. 2009, 68, 414-423. [CrossRef] [PubMed]

95. Coates, B.S.; Sumerford, D.V.; Hellmich, R.L.; Lewis, L.C. Partial mitochondrial genome sequences of Ostrinia nubilalis and Ostrinia furnicalis. Int. J. Biol. Sci. 2004, 1, 13-18. [CrossRef] [PubMed]

96. Kim, M.; Wan, X.; Kim, I. Complete mitochondrial genome of the seven-spotted lady beetle, Coccinella septempunctata (Coleoptera: Coccinellidae). Mitochondrial DNA 2012, 23, 179-181. [CrossRef]

97. Wang, Y.; Chen, J.; Jiang, L.Y.; Qiao, G.X. The complete mitochondrial genome of Mindarus keteleerifoliae (Insecta: Hemiptera: Aphididae) and comparison with other Aphididae insects. Int. J. Mol. Sci. 2015, 16, 30091-30102. [CrossRef]

98. Taanman, J.W. The mitochondrial genome: Structure, transcription, translation and replication. Biochim. Biophys. Acta 1999, 1410, 102-123. [CrossRef]

99. Hendrich, L.; Pons, J.; Ribera, I.; Balke, M. Mitochondrial cox1 sequence data reliably uncover patterns of insect diversity but suffer from high lineage-idiosyncratic error rates. PLoS ONE 2010, 5, e14448. [CrossRef]

(C) 2019 by the authors. Licensee MDPI, Basel, Switzerland. This article is an open access article distributed under the terms and conditions of the Creative Commons Attribution (CC BY) license (http://creativecommons.org/licenses/by/4.0/). 